\title{
Integrative taxonomy confirms that Gregarina garnhami and G. acridiorum (Apicomplexa, Gregarinidae), parasites of Schistocerca gregaria and Locusta migratoria (Insecta, Orthoptera), are distinct species
}

\author{
Isabelle Florent ${ }^{1, *}$, Marie Pierre Chapuis ${ }^{2,3}$, Amandine Labat ${ }^{1}$, Julie Boisard ${ }^{1,4}$, Nicolas Leménager ${ }^{2,3}$, Bruno Michel $^{2,3}$, \\ and Isabelle Desportes-Livage ${ }^{1}$ \\ ${ }^{1}$ Molécules de Communication et Adaptation des Microorganismes (MCAM, UMR 7245 CNRS), Département Adaptations du vivant \\ (AVIV), Muséum National d'Histoire Naturelle, CNRS, CP 52, 57 rue Cuvier, 75231 Paris Cedex 05, France \\ 2 CBGP, Univ Montpellier, CIRAD, INRAE, Institut Agro, IRD, 34060 Montpellier, France \\ ${ }^{3}$ CIRAD, UMR CBGP, 34398 Montpellier, France \\ ${ }^{4}$ Structure et instabilité des génomes (STRING UMR 7196 CNRS/INSERM U1154), Département Adaptations du vivant (AVIV), \\ Muséum National d'Histoire Naturelle, CNRS, INSERM, CP 26, 57 rue Cuvier, 75231 Paris Cedex 05, France
}

Received 28 July 2020, Accepted 2 February 2021, Published online 23 February 2021

\begin{abstract}
Orthoptera are infected by about 60 species of gregarines assigned to the genus Gregarina Dufour, 1828. Among these species, Gregarina garnhami Canning, 1956 from Schistocerca gregaria (Forsskål, 1775) was considered by Lipa et al. in 1996 to be synonymous with Gregarina acridiorum (Léger 1893), a parasite of several orthopteran species including Locusta migratoria (Linné, 1758). Here, a morphological study and molecular analyses of the SSU rDNA marker demonstrate that specimens of $S$. gregaria and specimens of L. migratoria are infected by two distinct Gregarina species, G. garnhami and G. acridiorum, respectively. Validation of the species confirms that molecular analyses provide useful taxonomical information. Phenotypic plasticity was clearly observed in the case of G. garnhami: the morphology of its trophozoites, gamonts and syzygies varied according to the geographical location of $S$. gregaria and the subspecies infected.
\end{abstract}

Key words: Gregarines, Orthoptera, Species delimitation, SSU rDNA phylogeny, Phenotypic plasticity, Biodiversity.

\begin{abstract}
Résumé - La taxonomie intégrative confirme que Gregarina garnhami et G. acridiorum (Apicomplexa, Gregarinidae), parasites de Schistocerca gregaria et Locusta migratoria (Insecta, Orthoptera), sont des espèces distinctes. Les orthoptères sont parasités par environ soixante espèces de grégarines affiliées au genre Gregarina Dufour, 1828. Parmi ces espèces Gregarina garnhami Canning, 1956 décrite chez Schistocerca gregaria (Forskål, 1775), a été mise en synonymie par Lipa et al. en 1996 avec Gregarina acridiorum (Léger 1893), parasite de plusieurs espèces d'orthoptères dont Locusta migratoria (Linné, 1758). Ici, une étude morphologique et des analyses moléculaires du marqueur SSU rDNA démontrent que les spécimens de $S$. gregaria et ceux de L. migratoria sont infectés par 2 espèces distinctes de grégarines, Gregarina garnhami et Gregarina acridiorum, respectivement. La validation de ces espèces confirme l'importance des informations fournies par les analyses moléculaires dans les études taxonomiques. Une plasticité phénotypique a été clairement observée dans le cas de G. garnhami : la morphologie de ses trophozoïtes, gamontes et syzygies varie selon la localisation géographique et la sous-espèce de $S$. gregaria infectée.
\end{abstract}

\section{Introduction}

Gregarines are a heterogeneous group of apicomplexan parasites that infect a very wide range of non-vertebrate hosts, in which they mostly occupy intestinal tracts and coelomic spaces [17]. The biodiversity of gregarines currently corresponds

\footnotetext{
*Corresponding author: isabelle.florent@mnhn. fr
}

to $1600-1700$ formally described species [32], but according to experts in the field, this number may be vastly underestimated $[1,17]$. Recent metagenomic surveys of terrestrial soils and marine environments further confirmed the high occurrence and abundance of gregarine-like sequences in these environments that remain to be ascribed to formally described species $[15,16,28]$. In the past, ascribing gregarine species assignations was based on combinations of morphological and behavioral 
features including parasitic life traits (host and host range specificities), the different locations occupied by the parasite in hosts (i.e. intestine or coelom), descriptions of life-cycle development stages (morphological measurements, duration of the stages, scanning and transmission electron microscopy), gamont pairing (frontal, lateral, caudo-frontal), and modes of gametocyst dehiscence $[11,17,26]$. The increasing use of molecular data in recent decades has led to the confirmation, but also sometimes to the revision of the taxonomic and phylogenetic view we have of gregarines, and has revealed that some species that were once considered distinct are in fact the same [19] or, the reverse, novel cryptic species, i.e. morphologically indistinguishable but clearly distinct at the molecular level [30].

Orthoptera (Ensifera (crickets and katydids) and Caelifera (grasshoppers, ground-hoppers and pygmy mole crickets)) are reported to be parasitized by about 60 species assigned to the genus Gregarina Dufour, 1828 (see [17] for a recent, extensive review of the literature). Based on morphological descriptions, some gregarine species have been found to be restricted to one host family or superfamily, while others seem to have the capacity to infect a wide range of hosts distributed worldwide $[14,17,36,37]$. Problems of identification based on morphological characters likely arose from phenotypic plasticity in response to wide-range host species and/or other contrasted environmental conditions. As a result, species delimitation within the genus Gregarina has been the subject of debate, with confusion, descriptions and synonymies, in particular for gregarines that infect the Caelifera suborder, as illustrated below. Species delimitation is, however, a global and recurrent issue in protistology [6].

In 1893, Léger described Clepsidrina acridiorum [24], which, a few years later, was termed Gregarina by Labbé (1899) [21]. This parasite was found in Acridoidea collected in Algeria [24]. As the infected specimens belonged to different genera of Caelifera (Truxalis, Pamphagus, Sphingonotus), Léger concluded that "other acridians from Africa should be investigated for potential G. acridiorum infections" [24]. Interestingly, he noticed that G. acridiorum was not found in the desert locust, Schistocerca gregaria [24]. Later in 1956, Canning described a gregarine she named Gregarina garnhami, sampled from this $S$. gregaria host [7]. Interestingly, G. garnhami was also reported by the same author in both the migratory locust, L. migratoria and in the Egyptian locust, Anacridium aegyptium [7]. According to data in the literature, G. acridiorum and G. garnhami share common morphological and behavioral characteristics, such as their development in the midgut of their hosts, a small globular epimerite, stout bodied gamonts, and barrel-shaped (or dolioform) oocysts [7, 23, 27]. In 1996, Lipa et al. concluded that the species described in 1956 by Canning in S. gregaria was in fact G. acridiorum [27]. This interpretation was supported by the fact that in 1956, Canning had not been aware of the existence of G. acridiorum [27]. Gregarina acridiorum has been reported in a range of Orthoptera hosts (Ensifera and Caelifera: Acrididae, Tetrigidae) including L. migratoria and A. aegyptium [12, 27], two species also described as hosts of G. garnhami [7]. Consequently, the two acridian species could be infected by the two gregarines species.
Gregarina acridiorum and G. garnhami also closely resemble Gregarina rigida (Hall, 1907) Ellis, 1913, described in a broad range of widely distributed orthopteran hosts [17] and also similar to Gregarina ronderosi, a parasite of the argentine grasshopper Dichroplus elongatus [22]. The developmental and morphological similarities of these four gregarines question their species definition as well as their host specificities and indeed, based on these similarities, in 1968, Corbel even proposed that G. rigida and G. acridiorum were the same [13]. Table 1 lists the main biological and morphological characters of these four very similar gregarines of acridians, plus data concerning a fifth species, Gregarina caledia (nomen nudum), a parasite of the Australian grasshopper Caledia captiva, described in the PhD Thesis of Jennifer Ann Ninham (1995) and reported to be very similar to G. garnhami [30]. Table 1 illustrates how tenuous some of these differences can be when these five gregarines of acridians are compared. The limited availability of DNA sequences corresponding to these species is an obstacle to the resolution of these controversies (only partial SSU rDNA sequences (1210 bp) are available for G. caledia (L31799) and Gregarina chortiocetes (L31841)). The latter species, an intestinal parasite of Chortiocetes terminifera, is however poorly described at the morphological level [30].

In 2002, Lange \& Wittenstein indicated that: "given the great similarity of Gregarina spp. associated with Acrididae, it would probably be very informative to study, at the molecular level, as many species as possible" [22]. To achieve this objective, we combined morphological and molecular data to better explore the species boundaries of gregarines that infect two orthopteran Acrididae hosts, S. gregaria (Forsskål, 1775) and L. migratoria (Linné, 1758). These two hosts are locusts, i.e. grasshoppers that can form dense migrating swarms, that are often destructive to agriculture, through an extreme form of density-dependent phenotypic plasticity, known as phase polyphenism [3, 41]. Here we sought to determine whether they are infected by the same or distinct gregarine species, as the information in the current literature is not congruent [7, 12-14, 21, 24, 27].

Morphological observations of the developmental stages of gregarines from L. migratoria and two subspecies of $S$. gregaria were performed and completed with the sequencing of their SSU rDNA loci. The results revealed clear molecular differences in this genetic marker, despite extremely similar morphological features, strongly supporting the hypothesis that these two acridian hosts are not infected by the same gregarine species. Some subtle morphological differences have also been identified between the two gregarine species.

\section{Materials and methods}

\section{Collection of hosts and isolation of parasites}

Specimens of L. migratoria (Linné, 1758) were obtained from the vivarium belonging to the French National Museum of Natural History (French acronym MNHN) (Source uncertain; time of establishment $>15$ years, regularly replenished from Insect Raising SARL (2, Chemin Champthiaud, 
25410 Dannemarie-sur-Crète, France). Two sub-species of the desert locust, $S$. gregaria, were studied: $S$. gregaria gregaria (Forsskål, 1775) and S. gregaria flaviventris (Burmeister, 1838), isolated in distinct regions along a north-south axis in Africa [10, 41]. The $S$. g. gregaria insects came from either a long-standing laboratory strain belonging to the team involved in molecular developmental physiology and signal transduction of the Department of Biology of Leuven University, Belgium (https://bio.kuleuven.be/df/jv; geographical source: Mauritania; time since establishment: several decades) or a long-standing laboratory strain acquired from the National Anti-Locust Centre in Agadir, Morocco, regularly replenished with individuals sampled in the field (geographical source: between Draa wadi and the Dakhla region; time of establishment: from the 1990s to 2014). Schistocerca gregaria gregaria egg pods from the two strains were received at the SEPA platform in CBGP on May 30 and June 12, 2014, respectively, and hatchlings were crowd-reared before treatment (July 17 and 23, 2014) in a breeding chamber at $32{ }^{\circ} \mathrm{C}$, with $50 \%$ humidity, with a $12 \mathrm{~h}: 12 \mathrm{~h}$ photoperiod, and fed with seedling wheat, supplemented by wheat bran for adults. The $S$. g. flaviventris insects came from a natural population in Tankwa Karoo National Park, South Africa $\left(20.03^{\circ} \mathrm{E} ;-32.23^{\circ}\right)$, in which 70 nymphs were collected on February 23, 2014 and taken to the SEPA platform in CBGP for two generations of maintenance before treatment on July 11 and July 18, 2014, in the same breeding chamber and under the same conditions.

The hosts used in this study and the dates of sampling for biological analyses are listed in Table 2 . All acridian specimens were anesthetized with chloroform. Their digestive tract was dissected in $0.22 \mu \mathrm{m}$-filtered sterile PBS $1 \mathrm{X}$ and gamonts (solitary or in syzygies) and gametocysts were isolated from ceca and midguts (S. gregaria) or only midguts (L. migratoria) using tweezers and sterile elongated Pasteur pipettes, under a stereomicroscope. Gametocysts were also occasionally isolated from insect feces and kept at room temperature to observe dehiscence. All isolated gregarines were washed at least three times in $0.22 \mu \mathrm{m}$-filtered sterile PBS $1 \mathrm{X}$ to eliminate host tissue and environmental bacteria prior to being used for microscopic observations, fixed for scanning electron microscopy, or stored as cell pellets at $-20{ }^{\circ} \mathrm{C}$ prior to genomic DNA extraction.

\section{Morphological studies}

Isolated parasites were first observed on slides using light microscopy. Images were acquired using a Nikon DXM 1200C camera and a micrometric slide to set the scales, and the images were processed using ImageJ software (https:// imagej.nih.gov/ij/). In parallel, pools of isolated and washed gamonts and gametocysts and relevant sections of infected acridian ceca and midguts were prepared for scanning electron microscopy (SEM). After appropriate washing in $0.22 \mu \mathrm{m}$-filtered sterile PBS $1 \mathrm{X}$, the samples were fixed in $5 \%(\mathrm{v} / \mathrm{v})$ glutaraldehyde in $0.2 \mathrm{M}$ cacodylate buffer $(\mathrm{pH} 7.2)$ at $4{ }^{\circ} \mathrm{C}$ for $6-12 \mathrm{~h}$ then washed twice in $0.2 \mathrm{M}$ cacodylate buffer $(\mathrm{pH} 7.2)$ before undergoing successive series of dehydration in 50, 70, 90 and $100 \%$ ethanol. Samples were critical point-dried in liquid $\mathrm{CO}_{2}$ (Emitech K850, Quorum Technologies, Lewes, United Kingdom) then coated with $20 \mathrm{~nm}$ gold (JFC-1200 Fine coater,
JEOL, Tokyo, Japan). Samples were then examined with a Hitachi Scanning Electron Microscope SU3500 Premium (Hitachi, Tokyo, Japan), as previously described [2]. Quantitative measurements were length and width at the different life stages, including length of protomerites and deutomerites for trophozoites and gamonts.

\section{Statistical tests}

In order to compare the averages of the measurements carried out for the gregarines infecting either S. gregaria or L. migratoria hosts, statistical tests were performed as follows. For the group of measurements with $n=18$, we used a Shapiro-Wilk Test to assess the normality of the data, which established normality. For this sample and all the other groups of measurements tested with $n>30$, we used parametric tests. First, a Fisher test was conducted to test the homoscedasticity of the variances within the groups. When homoscedasticity was retrieved, we conducted a Student's $t$-test to compare the means of each group. When homoscedasticity was not retrieved, we then used a Welch's $t$-test. Analyses were performed using R software.

\section{DNA extraction and sequencing}

Total genomic DNA was extracted from pools of parasites (gamonts or gametocysts), isolated from individual host specimens as indicated in Table 3, using standard phenol-chloroform extractions [34] or MasterPure ${ }^{\mathrm{TM}}$ Complete DNA and RNA Purification kits (Epicentre Biotechnologies, Madison, WI, USA), as previously described [35]. Isolated nucleic acids were subsequently used as templates in standard PCR reactions designed to amplify most of the SSU rDNA loci (V1-V8) [18], using forward WL1 - 5'-GCGCTACCTGGTTGATCCTGCC $-3^{\prime}$ and reverse EukP3 5'-GACGGGCGGTGTGTAC$3^{\prime}$ primers, as previously described [35]. After confirmation of the appropriate amplicon size by agarose-gel electrophoresis, PCR products were purified using an Illustra ${ }^{\mathrm{TM}} \mathrm{GFX}^{\mathrm{TM}} \mathrm{PCR}$ DNA and Gel Band Purification Kit (GE Healthcare, France), and cloned into a pGEM $^{\circledR}$-T Easy Vector (Promega, Madison WI, USA), as previously described [35, 39]. DNA sequences were obtained by Sanger technology (Beckman Coulter Genomics, Takeley, United Kingdom) from positive clones selected by PCR using the T7 and Sp6 universal primers that flank the pGEM $^{\circledR}$-T Easy Vector cloning site, as previously described [39]. In addition to using T7 and Sp6 as sequencing primers, several internal primers were used (LWA3 5'-AAACTTAAAGGAATTGACGG-3'; PIF4F 5'-CCGTTACTTTGAGCAAATTGG-3'; PIF4R 5'-CTTAGAATTTCACCTCTCT$\left.\mathrm{CC}-3^{\prime}\right)$. SSU rDNA loci were then aligned and assembled from raw data using MEGA X [20]. The 43 novel sequences were deposited in the European Nucleotide Archive (ENA) database under accession numbers: LR814064-LR814106 (http://www. ebi.ac.uk/ena/data/view/LR814064-LR814106).

\section{Phylogenetic analyses}

Using maximum likelihood (ML) and Bayesian methods, phylogenetic trees were built from 69 sequences from 
Table 1. Morphological differences between five very similar gregarines of acridians reported in the literature. This table is based on individual descriptions provided by the authors of [7,21, 22, 24, 30]; see also [17]. $D$, diameter; $L$, length; $W$, width; TL, total length.

\begin{tabular}{|c|c|c|c|c|c|}
\hline Gregarine & $\begin{array}{l}\text { Gregarina acridiorum } \\
\text { (Léger, 1893) Labbé, } \\
1899 \text { [24] [21] }\end{array}$ & $\begin{array}{l}\text { Gregarina } \\
\text { garnhami } \\
\text { Canning, } \\
1956[7]\end{array}$ & $\begin{array}{c}\text { Gregarina rigida } \\
\text { (Hall, 1907) Ellis, } \\
1913 \text { [17] }\end{array}$ & $\begin{array}{l}\text { Gregarina ronderosi, } \\
\text { Lange \& Wittenstein, } \\
2002 \text { [22] }\end{array}$ & $\begin{array}{l}\text { Gregarina caledia, } \\
\text { Ninham, } 1995 \text { [30] }\end{array}$ \\
\hline Hosts & $\begin{array}{l}\text { Caelifera: Acrididae, } \\
\text { Tetrigidae; Ensifera: } \\
\text { Tettigoniidae }\end{array}$ & Caelifera: Acrididae & $\begin{array}{l}\text { Caelifera: Acrididae; } \\
\text { Ensifera: } \\
\text { Tettigoniidae }\end{array}$ & Caelifera: Acrididae & $\begin{array}{l}\text { Caelifera: } \\
\text { Acrididae }\end{array}$ \\
\hline $\begin{array}{l}\text { Infected sites } \\
\text { in hosts }\end{array}$ & Midgut & $\begin{array}{l}\text { Early stages in gastric } \\
\text { ceca and } \\
\text { occasionally in the } \\
\text { midgut; gamonts in } \\
\text { the midgut }\end{array}$ & $\begin{array}{l}\text { Early stages in gastric } \\
\text { ceca, near the } \\
\text { anterior end of the } \\
\text { midgut }\end{array}$ & $\begin{array}{l}\text { Trophozoites, solitary } \\
\text { or associated } \\
\text { gamonts in gastric } \\
\text { ceca and gut; } \\
\text { gametocysts in the } \\
\text { hindgut }\end{array}$ & $\begin{array}{l}\text { Trophozoites, } \\
\text { solitary or } \\
\text { associated } \\
\text { gamonts in } \\
\text { gastric ceca and } \\
\text { midgut; } \\
\text { gametocysts in } \\
\text { the hindgut }\end{array}$ \\
\hline \multicolumn{6}{|c|}{ Trophozoites - gamonts } \\
\hline \multirow[t]{3}{*}{ Gamonts } & $\begin{array}{l}\text { Gamonts: cylindrical, } \\
\text { ovoid in older } \\
\text { forms, endocyte } \\
\text { yellow orange. }\end{array}$ & $\begin{array}{l}\text { Gamonts: rather stout } \\
\text { bodied in older } \\
\text { forms, endocytes are } \\
\text { pale yellow. }\end{array}$ & $\begin{array}{l}\text { Gamonts: rather stout } \\
\text { bodied, endocytes } \\
\text { are brownish orange. }\end{array}$ & $\begin{array}{l}\text { Trophozoite } \\
\quad \text { (epimerite): } L: 10.4- \\
275 \mu \mathrm{m} \text {, more } \\
\text { slender than }\end{array}$ & $\begin{array}{l}\text { Gamonts: pale- } \\
\text { yellow, ovoid } \\
\text { then cylindrical }\end{array}$ \\
\hline & $\begin{array}{l}L: \sim 400 \mu \mathrm{m}, \\
W: 160 \mu \mathrm{m}\end{array}$ & $L: 250-554 \mu \mathrm{m}$ & $\begin{array}{l}L: 250-750 \mu \mathrm{m} \\
W: 130-210 \mu \mathrm{m}\end{array}$ & $\begin{array}{l}\text { gamonts; Gamonts: } \\
\text { rather stout bodied, } \\
\text { endocytes are pale } \\
\text { yellow. }\end{array}$ & $\begin{array}{l}L: 180-264 \mu \mathrm{m} \\
W: 60-70 \mu \mathrm{m} \\
\text { Mean: } \\
222 \mu \mathrm{m} \times 65 \mu \mathrm{m}\end{array}$ \\
\hline & & & & $L: 80-348 \mu \mathrm{m}$ & \\
\hline $\begin{array}{l}\text { Association } \\
\text { Length }\end{array}$ & TL: up to $1000 \mu \mathrm{m}$ & TL: $500-1110 \mu \mathrm{m}$ & $\begin{array}{l}\text { TL: up to } 1425 \mu \mathrm{m} \\
\text { (average: } 550 \mu \mathrm{m} \text { ). } \\
\text { Protomerite smaller } \\
\text { in the satellite than } \\
\text { in the primite }\end{array}$ & $\begin{array}{l}\text { TL: } 160-700 \mu \mathrm{m} \\
\text { (average: } 425 \mu \mathrm{m} \text { ). } \\
\text { Primites and } \\
\text { satellites are similar } \\
\text { in size and shape }\end{array}$ & $\begin{array}{l}\text { TL: } 515 \mu \mathrm{m} . \\
\text { Primites and } \\
\text { satellites are } \\
\text { similar in size. } \\
\text { Also seen: } \\
\text { primite with } 2 \\
\text { small satellites }\end{array}$ \\
\hline Epimerite & $\begin{array}{l}\text { Small, spherical with a } \\
\text { short stalk. }\end{array}$ & $\begin{array}{l}\text { Small, globular with a } \\
\text { short stalk. }\end{array}$ & $\begin{array}{l}\text { Small spherical hyaline } \\
\text { knob. }\end{array}$ & $\begin{array}{l}\text { Conical when attached, } \\
\text { globular and smaller } \\
\text { in free trophozoites }\end{array}$ & Globular \\
\hline Protomerite & $\begin{array}{l}\text { Sub-globular in } \\
\text { primites, depressed } \\
\text { at the anterior end in } \\
\text { satellites. }\end{array}$ & $\begin{array}{l}\text { Conical in young } \\
\text { stages, subspherical } \\
\text { in older stages, } \\
\text { widest at the septum, } \\
\text { tapering towards the } \\
\text { anterior end, } \\
\text { flattened in satellite. }\end{array}$ & $\begin{array}{l}\text { Somewhat flattened, } \\
3 \text { times wider than } \\
\text { long, generally less } \\
\text { constriction at } \\
\text { septum more or less } \\
\text { indistinct. }\end{array}$ & $\begin{array}{l}\text { Sub-globular in } \\
\text { primites, depressed } \\
\text { at anterior end in } \\
\text { satellites, less } \\
\text { flattened than in } \\
\text { G. garnhami }\end{array}$ & $\begin{array}{l}\text { Rounded anterior } \\
\text { end }\end{array}$ \\
\hline Deutomerite & $\begin{array}{l}\text { Cylindrical, rounded } \\
\text { posterior end }\end{array}$ & $\begin{array}{l}\text { Cylindrical or rounded, } \\
\text { with sharply pointed } \\
\text { posterior end }\end{array}$ & $\begin{array}{l}\text { Cylindrical or barrel- } \\
\text { shaped, little wider } \\
\text { than protomerite, } \\
\text { broadly rounded end } \\
\text { or flattened } \\
\text { "cornered" } \\
\text { extremity }\end{array}$ & $\begin{array}{l}\text { Cylindrical, rounded } \\
\text { posterior end, wider } \\
\text { than protomerite, } \\
\text { barrel-shaped in } \\
\text { older forms }\end{array}$ & $\begin{array}{l}\text { Cylindrical, in } \\
\text { small gamonts, } \\
\text { wider than in } \\
\text { protomorites and } \\
\text { rounded in older } \\
\text { forms }\end{array}$ \\
\hline \multicolumn{6}{|c|}{ Gametocysts - oocysts } \\
\hline Gametocysts & $\begin{array}{l}D: 500 \mu \mathrm{m} \text {, thick } \\
\quad \text { ectocyst }\end{array}$ & $\begin{array}{l}D: 114-470 \mu \mathrm{m} \\
\quad \text { (exclusive of the } \\
\text { ectocyst) }\end{array}$ & $\begin{array}{l}D: 300 \mu \mathrm{m} \text { in average. } \\
\text { Yellow orange } \\
\text { color. Thick ectocyst }\end{array}$ & $\begin{array}{l}D: 96-376 \mu \mathrm{m} . \\
\text { Thick ectocyst }\end{array}$ & $\begin{array}{l}D: 228-312 \mu \mathrm{m} \\
\text { (mean } 270 \mu \mathrm{m}) \\
\text { Yellow orange } \\
\text { color. Ectocyst } \\
(24-100 \mu \mathrm{m} \\
\text { thick) }\end{array}$ \\
\hline
\end{tabular}


Table 1. (Continued)

\begin{tabular}{|c|c|c|c|c|c|}
\hline Gregarine & $\begin{array}{l}\text { Gregarina acridiorum } \\
\text { (Léger, 1893) Labbé, } \\
1899 \text { [24] [21] }\end{array}$ & $\begin{array}{l}\text { Gregarina } \\
\text { garnhami } \\
\text { Canning, } \\
1956[7]\end{array}$ & $\begin{array}{c}\text { Gregarina rigida } \\
\text { (Hall, 1907) Ellis, } \\
1913[17]\end{array}$ & $\begin{array}{c}\text { Gregarina ronderosi, } \\
\text { Lange \& Wittenstein, } \\
2002[22]\end{array}$ & $\begin{array}{l}\text { Gregarina caledia, } \\
\text { Ninham, } 1995 \text { [30] }\end{array}$ \\
\hline Basal discs & Yellow orange & Yellow orange & Not mentioned & Orange & Orange \\
\hline Sporoducts & $\begin{array}{l}\text { 12-15, with a swollen } \\
\text { basal part, } L>1 / 2 \\
\text { cyst diameter }\end{array}$ & $\begin{array}{l}8, L: 1 / 3 \text { cyst diameter } \\
\text { (without ectocyst) }\end{array}$ & 10 or more, short & $12-15, L:$ up to $60 \mu \mathrm{m}$ & 5 to more than 10 \\
\hline \multirow{2}{*}{$\begin{array}{l}\text { Oocysts } \\
\text { (sporo- } \\
\text { cysts) }\end{array}$} & $\begin{array}{l}\text { Dolioform*, } \\
\text { double wall }\end{array}$ & $\begin{array}{l}\text { Dolioform*, } \\
\text { thick wall }\end{array}$ & & $\begin{array}{l}\text { Dolioform* } \\
\quad \text { or Barrel-shaped* }\end{array}$ & Barrel-shaped* \\
\hline & $7.6 \mu \mathrm{m} \times 3.3 \mu \mathrm{m}$ & $6.5-7 \mu \mathrm{m} \times 4 \mu \mathrm{m}$ & $8 \mu \mathrm{m} \times 5 \mu \mathrm{m}$ & $5 \mu \mathrm{m} \times 3.2 \mu \mathrm{m}$ & $12 \mu \mathrm{m} \times 6 \mu \mathrm{m}$ \\
\hline
\end{tabular}

*Depending on the authors, the terms "dolioform" and/or "barrel-shaped" were used to describe the shape of oocysts. Note also that oocysts were called sporocysts in all these historical descriptions.

Table 2. Acrididae hosts used in this study, sampling dates, host status and sampled gregarines. "Sick" hosts died rapidly (within days) in laboratory conditions in contrast to "healthy" hosts that were maintained for weeks.

\begin{tabular}{|c|c|c|c|}
\hline $\begin{array}{l}\text { Acrididae host/designation in } \\
\text { study }\end{array}$ & Source & Host status & Gregarines sampled \\
\hline $\begin{array}{l}\text { Schistocerca gregaria } \\
\quad \text { gregaria }(2014) / \mathbf{S G}-\mathbf{M}\end{array}$ & $\begin{array}{l}\text { Long-standing laboratory strain } \\
\text { from CNLA Agadir, Morocco }\end{array}$ & Sick & $\begin{array}{l}\text { Young trophozoites in ceca, gamonts, syzygies and } \\
\text { gametocysts in the midgut, occasionally gametocysts } \\
\text { in feces; high infection level }\end{array}$ \\
\hline $\begin{array}{l}\text { Schistocerca gregaria } \\
\quad \text { gregaria }(2014) / \text { SG-B }\end{array}$ & $\begin{array}{l}\text { Long-standing laboratory strain } \\
\text { from KU Leuven, Belgium }\end{array}$ & Healthy & $\begin{array}{l}\text { Young trophozoites in ceca, gamonts, syzygies and } \\
\text { gametocysts in the midgut, occasionally gametocysts } \\
\text { in feces; high infection level }\end{array}$ \\
\hline $\begin{array}{l}\text { Schistocerca gregaria } \\
\quad \text { flaviventris }(2014) / \mathbf{S G - S A}\end{array}$ & $\begin{array}{l}\text { Natural population from Tankwa } \\
\text { Karoo National Park, South } \\
\text { Africa }\end{array}$ & Sick & $\begin{array}{l}\text { Young trophozoites in ceca, gamonts, syzygies and } \\
\text { gametocysts in the midgut, occasionally gametocysts } \\
\text { in feces; high infection level }\end{array}$ \\
\hline $\begin{array}{l}\text { Locusta migratoria }(2012, \\
\text { 2014, 2015)/LM-M }\end{array}$ & $\begin{array}{l}\text { Long-standing laboratory strain from } \\
\text { MNHN Vivarium, France }\end{array}$ & Healthy & $\begin{array}{l}\text { Gamonts, syzygies and gametocysts in the midgut, } \\
\text { occasionally gametocysts in feces; mild infection } \\
\text { level }\end{array}$ \\
\hline
\end{tabular}

gregarines infecting either $S$. gregaria (20 sequences), L. migratoria (23 sequences), a range of different insect hosts (22 sequences) or marine crustaceans, chosen as the gregarine outgroup specimen (4 sequences) $[11,30,35]$. Using a previously published alignment [35], the new gregarine sequences were added manually to yield a confident alignment of 1433 positions, after selection of conserved blocks defined using Gblocks 0.91b [8] (parameters used: Minimum Number Of Sequences For A Conserved Position: 35; Minimum Number Of Sequences For A Flanking Position: 58; Maximum Number Of Contiguous Nonconserved Positions: 8; Minimum Length Of A Block: 3; Allowed Gap Positions: With Half Use Similarity Matrices: Yes). A GTR substitution model with gammadistributed rate variation across sites and a proportion of invariant sites was suggested as the best-fit model by MEGA X [20]. A Bayesian phylogenetic tree was constructed with MrBayes v3.2.3 [33] using lset $n=6$ rates = invgamma parameters; Monte Carlo Markov Chain parameters were mcmc ngen $=10000000$ relburnin $=$ yes burninfrac $=0.25$ samplefreq $=1000$ printfreq $=10000$ nchains $=4$ nruns $=2$. A consensus tree was constructed from the post burn-in trees and posterior probabilities were calculated in MrBayes. Posterior probabilities $>0.95$ were considered strong support. Maximum likelihood analyses were performed using RAxML version 8.2.12 [40] using the GTR + G + I model; bootstraps were estimated from 1000 replicates. Bootstrap percentages $>75 \%$ were considered good support. Trees were visualized and edited with FigTree and Inkscape.

\section{Estimates of genetic divergence between and within groups}

The numbers of base differences per site from averaging over all sequence pairs between and within each group were calculated using MEGA X [20]. This analysis involved 44 nucleotide sequences: 20 from gregarines that infect $S$. gregaria, 23 from gregarines that infect $L$. migratoria, and the sequence of $G$. caledia that infects $C$. captiva (L31799). For each sequence pair, all ambiguous positions were removed (pairwise deletion option) leaving a total of 1784 positions in the final dataset. From this dataset, we also constructed a minimum spanning network to analyze the relationships among the cloned SSU rDNA sequences using POPART [25]. 
Table 3. Gregarine specimens isolated for molecular investigation.

\begin{tabular}{|c|c|c|c|c|}
\hline Host & $\begin{array}{l}\text { Geographical origin } \\
\text { and collection date }\end{array}$ & $\begin{array}{l}\text { Number of isolated } \\
\text { parasite stages }\end{array}$ & $\begin{array}{l}\text { gDNA preparation } \\
\text { (name, method) }\end{array}$ & $\begin{array}{c}\text { Parasite clones } \\
\text { (clone designations) }\end{array}$ \\
\hline Locusta migratoria & MNHN 2012 & Gamonts (50) & LW, Phenol chloroform & LM1.01.M.2012-1 \\
\hline Locusta migratoria & MNHN 2014 & Gamonts (50) & JF, MasterPure & LM2.01.M.2014-2 \\
\hline Locusta migratoria & MNHN 2015 & Gametocysts (20) & JS310, MasterPure & $\begin{array}{l}\text { LM3.01.M.2015-3 } \\
\text { LM3.02.M.2015-4 } \\
\text { LM3.03.M.2015-5 } \\
\text { LM3.04.M.2015-6 } \\
\text { LM3.05.M.2015-7 }\end{array}$ \\
\hline Locusta migratoria & MNHN 2015 & Gametocysts (17) & JS311, MasterPure & $\begin{array}{l}\text { LM4.01.M.2015-8 } \\
\text { LM4.02.M.2015-9 } \\
\text { LM4.03.M.2015-10 } \\
\text { LM4.04.M.2015-11 }\end{array}$ \\
\hline Locusta migratoria & MNHN 2015 & Gametocysts (13) & JS312, MasterPure & $\begin{array}{l}\text { LM5.01.M.2015-12 } \\
\text { LM5.02.M.2015-13 } \\
\text { LM5.03.M.2015-14 } \\
\text { LM5.04.M.2015-15 }\end{array}$ \\
\hline Locusta migratoria & MNHN 2015 & Gametocysts (13) & JS313, MasterPure & $\begin{array}{l}\text { LM6.01.M.2015-16 } \\
\text { LM6.02. M.2015-17 } \\
\text { LM6.03. M.2015-18 } \\
\text { LM6.04. M.2015-19 } \\
\text { LM6.05. M.2015-20 }\end{array}$ \\
\hline Locusta migratoria & MNHN 2015 & Gametocysts (17) & JS314, MasterPure & $\begin{array}{l}\text { LM7.01. M.2015-21 } \\
\text { LM7.02. M.2015-22 } \\
\text { LM7.03. M.2015-23 }\end{array}$ \\
\hline $\begin{array}{l}\text { Schistocerca gregaria } \\
\quad \text { flaviventris }\end{array}$ & South Africa 2014 & $\begin{array}{l}\text { Gamonts (10) and } \\
\text { Gametocysts (10) }\end{array}$ & JS260, MasterPure & $\begin{array}{l}\text { SG1.01.SA.2014-24 } \\
\text { SG1.02.SA.2014-25 } \\
\text { SG1.03.SA.2014-26 } \\
\text { SG1.04.SA.2014-27 }\end{array}$ \\
\hline $\begin{array}{l}\text { Schistocerca gregaria } \\
\quad \text { flaviventris }\end{array}$ & South Africa 2014 & Gametocysts (9) & JS261, MasterPure & $\begin{array}{l}\text { SG2.01.SA.2014-28 } \\
\text { SG2.02.SA.2014-29 } \\
\text { SG2.03.SA.2014-30 } \\
\text { SG2.04.SA.2014-31 } \\
\text { SG2.05.SA.2014-32 }\end{array}$ \\
\hline $\begin{array}{l}\text { Schistocerca gregaria } \\
\quad \text { flaviventris }\end{array}$ & South Africa 2014 & Gamonts $(\sim 250)$ & JS269, MasterPure & $\begin{array}{l}\text { SG3.01.SA.2014-33 } \\
\text { SG3.02.SA.2014-34 } \\
\text { SG3.03.SA.2014-35 }\end{array}$ \\
\hline $\begin{array}{l}\text { Schistocerca gregaria } \\
\quad \text { gregaria }\end{array}$ & Belgium 2014 & Gamonts ( 200) & JS267, MasterPure & $\begin{array}{l}\text { SG4.01.B.2014-36 } \\
\text { SG4.02.B.2014-37 } \\
\text { SG4.03.B.2014-38 } \\
\text { SG4.04.B.2014-39 } \\
\text { SG4.05.B.2014-40 } \\
\text { SG4.06.B.2014-41 } \\
\text { SG4.07.B.2014-42 }\end{array}$ \\
\hline $\begin{array}{l}\text { Schistocerca gregaria } \\
\text { gregaria }\end{array}$ & Morocco 2014 & $\begin{array}{l}\text { Young trophozoites } \\
\text { in ceca }(\sim 400)\end{array}$ & JS272, MasterPure & SG5.01.Ma.2014-43 \\
\hline
\end{tabular}

\section{Results}

Gregarines isolated from the intestinal tracts of various acridian $S$. gregaria and L. migratoria host specimens (Table 2) were mostly located between the host intestine epithelial cells and digested food material. In addition, in all S. gregaria specimens, young trophozoite stages were invariably observed in the host's ceca, whereas this was never observed in L. migratoria. Occasionally, gametocysts were also isolated from insect feces and kept at room temperature to observe dehiscence. The observed stages were trophozoites, solitary gamonts, gamonts associated in caudo-frontal syzygies, and gametocysts enclosing oocysts or emitting them as chains through sporoducts (Fig. 1).

\section{Morphological description of gregarines of Schistocerca gregaria}

Young trophozoite stages (also referred to as cephalonts in historical publications [7, 17, 30]) (Fig. 1A) were observed in the two subspecies, regardless of the geographical location/ raising facilities (Table 2). The globular epimerite with a short neck was visible in their anterior part (Fig. 1A). The density of infections could be very high, as shown by the number of trophozoites attached to the gut epithelium of an $S$. g. gregaria host from Morocco (Fig. 1B). The epimerite of attached trophozoites was enclosed in the host epithelial cell (Fig. 1C). High densities of trophozoites were also found in the ceca (data not shown) and midgut (solitary gamonts and syzygies 

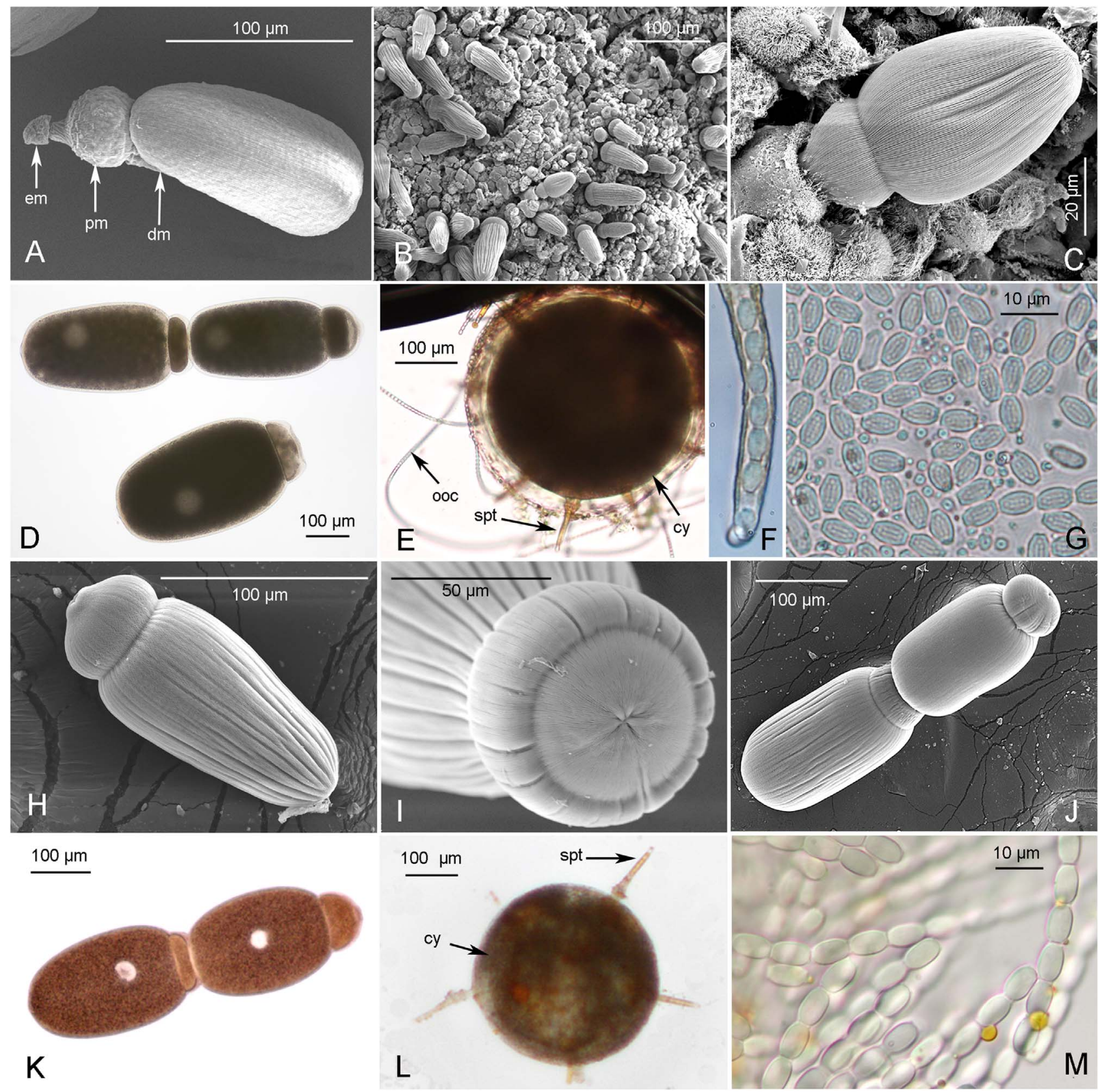

Figure 1. Scanning Electron Microscopy (A-C, H-J) and photonic imaging (D-G, K-M) of gregarines infecting S. gregaria (A-G) and L. migratoria (H-M). S. gregaria gregarines: A, young trophozoite (epimerite (em) protomerite (pm) and deutomerite (dm)), (South Africa); $\mathrm{B}$, intestinal tract infected by numerous gregarines (Morocco); C, gregarine encased in an intestinal host cell, enlargement of B (Morocco); D. Solitary gamont and syzygy (Belgium); E. Gametocyst form (cy) with developed sporoducts (spt) releasing oocyst chains (ooc); F, zoom on sporoduct extremity showing enclosed oocysts; G. released oocysts. L. migratoria gregarines: H, solitary gamont detached from intestinal host cell; I. zoom on gamont protomerite; J-K, gamonts associated in syzygies; L, Gametocyst form (cy) with developed sporoducts (spt); M. released oocysts. Scales are given for each figure.

(Fig. 1D)). The protomerite of trophozoites and gamonts was oval or slightly conical (Figs. 1A-1D); in syzygies, it appeared to be flattened at the top of the satellite with a ridge formed during pairing with the primite (Fig. 1D). Scanning electron microscopy revealed a similar ridge at the top of the satellite in G. garnhami syzygies [42]. The deutomerite was cylindrical or ovoid, and quite stocky in older trophozoites and syzygies (Fig. 1D). A constriction of the septum was visible between the posterior part of the protomerite and the anterior part of the deutomerite (Fig. 1D). The nucleus was seen in the opaque endocyte of the deutomerite. Longitudinal epicytic folds were visible at the surface of these trophozoite/gamont stages (Figs. 1A-1C). Thickening of the ectocyte was visible above the endocyte at the apex of the primite protomerite (Fig. 1D).

The gamonts in $S$. g. flaviventris from South Africa $(L$ (length) $=402 \pm 79 \mu \mathrm{m}, W$ (width) $=172 \pm 42 \mu \mathrm{m}$, $n=27$ ) were very similar in size to gamonts in $S$. g. gregaria from Belgium $(L=410 \pm 53 \mu \mathrm{m}, W=200 \pm 39 \mu \mathrm{m}, n=34)$, 
but slightly smaller in $S$. g. gregaria from Morocco ( $L=332 \pm 43 \mu \mathrm{m}, W=96 \pm 16 \mu \mathrm{m}, n=4)$. Moreover, smaller and much thinner trophozoites were observed in the latter $(L=192 \pm 15 \mu \mathrm{m}, W=34 \pm 4 \mu \mathrm{m}, n=12)$ (Fig. 1A). Also interestingly, gamonts in $S$. g. gregaria from Belgium were much stockier $(L / W=2.1 \pm 0.2)$ than gamonts in $S$. g. flaviventris from South Africa $(L / W=2.4 \pm 0.3)$ and gamonts $(L / W=3.5 \pm 0.2)$ and trophozoites $(L / W=5.8 \pm 1.0)$ in $S$. g. gregaria from Morocco. The ratios of protomerite (P) to deutomerite (D) lengths were, however, similar for gamonts, regardless of the infected hosts $(\mathrm{P} / \mathrm{D}=0.25 \pm 0.04$ (South Africa, $n=27$ ); $\mathrm{P} / \mathrm{D}=0.23 \pm 0.06$ (Belgium, $n=34$ ); $\mathrm{P} / \mathrm{D}=0.23 \pm 0.07$ (Morocco, $n=4$ ), and also for the thinner trophozoites found in Moroccan S. g. gregaria specimens $(\mathrm{P} / \mathrm{D}=0.26 \pm 0.04$, $n=12$ ). Overall, for trophozoites and gamonts infecting these hosts, regardless of the subspecies and their geographical location, the values were: $L=370 \pm 98 \mu \mathrm{m} ; W=159 \pm 69$; $L / W=2.83 \pm 1.38(n=77)$.

Gametocysts in dehiscence were observed, producing $\sim 8$ (but sometimes more) pale orange basal discs, circular cellular structures with a central opening that eventually developed across the mucilaginous layer (ectocyst) into sporoducts with swollen bases (Fig. 1E). Their length was $\sim 1 / 3$ that of the diameter of the gametocyst (Fig. 1E). Gametocysts diameters were $350 \pm 56 \mu \mathrm{m}, n=36$ (from 210 to $420 \mu \mathrm{m}$ ). Oocysts extruding as chains through these sporoducts (Fig. 1F) were barrel-shaped with a thick wall enclosing eight sporozoites (Fig. 1G). Their size was quite uniform $(L=6.54 \pm 0.32 \mu \mathrm{m}$, $W=4.32 \pm 0.23 \mu \mathrm{m}, n=89$ ) (Fig. 1G).

\section{Morphological description of gregarines of Locusta migratoria}

Trophozoite stages attached to the gut epithelium of hosts were not seen, but a scar remained visible where the epimerite had been present at the top of the protomerite of detached gamonts (Figs. 1H-1I). These gamonts were rather cylindrical with a sub-globular protomerite, flattened and slightly constricted at the proto-deutomerite septum (Figs. 1H, 1J, 1K). The deutomerite was much longer and more slender towards the posterior end (Fig. 1H). The size of the gamonts varied but the mean size $(L=219 \pm 48 \mu \mathrm{m}, W=93 \pm 30 \mu \mathrm{m}$, $n=37$ ) was smaller than the mean size observed in $S$. gregaria specimens (see above). Gamonts were also quite stocky $(L / W=2.5 \pm 0.6, n=37)$. In caudo-frontal syzygies, the protomerite was sub-globular in the primite, but shorter and flattened with a circular anterior edge in the satellite (Figs. 1J-1K). The deutomerite was cylindrical, slightly wider in the anterior part (Fig. 1J), ovoid in syzygies (Fig. 1K), with a rounded posterior end. The spherical nucleus could be seen in the opaque cytoplasm (endocyte) of the deutomerite (Fig. 1K). Longitudinal epicytic folds were seen at the surface of these stages (Figs. 1H-1J). The length of these syzygies was $(L=456 \pm 73 \mu \mathrm{m}, W=93 \pm 30 \mu \mathrm{m}, n=16)$ in our studies. The ratio of protomerite (P) deuteromerite (D) lengths was $\sim 1 / 4(\mathrm{P} / \mathrm{D}=0.25 \pm 0.05, n=21)$. Gametocysts were spherical with a mucilaginous layer (ectocyst). Under this layer, and as observed in gregarines that infect $S$. gregaria, basal discs of the future sporoducts differentiated at the surface of encysted gametocysts. These basal discs were also orange with a central white aperture, but were fewer in number $(<8, n=15)$. Like in the case of gregarines that infect $S$. gregaria, chains of oocysts were extruded through sporoducts (Figs. 1L-1M) whose length in gregarines of $L$. migratoria is longer and represents $\sim 1 / 2$ the diameter of the gametocyst (Fig. 1L). Gametocysts diameters were $227 \pm 35 \mu \mathrm{m}, n=18$ (from 190 to $296 \mu \mathrm{m}$ ). Oocysts, that were also emitted as chains from sporoducts, were also barrelshaped with a double wall but were slightly longer and slimmer $(L=6.83 \pm 0.27 \mu \mathrm{m}, W=3.99 \pm 0.19 \mu \mathrm{m}, n=40$, Fig. $1 \mathrm{M})$ than the oocysts emitted by gregarines that infect $S$. gregaria (Figs. 1G, 1F).

\section{Statistical comparison of morphological measurements}

For the gamonts, the means of the lengths ( $p$-value $=$ $2.2 \mathrm{e}-16 ; d f$ (degree of freedom $)=111.97)$ and of the widths $(p$-value $=8.574 \mathrm{e}-11 ; d f=111.13)$ were significantly different between the gregarines infecting $S$. gregaria and L. migratoria. However, there were no significant differences between the length/width ratios between these two groups. Concerning the gametocysts diameters, the mean was significantly different ( $p$-value $=1.986 \mathrm{e}-13 ; d f=49.386)$. Finally, for the oocysts, both mean length ( $p$-value $=6.664 \mathrm{e}-07 ; d f=89.407$ ) and mean width $(p$-value $=5.722 \mathrm{e}-13 ; d f=88.967)$ were significantly different.

\section{SSU rDNA sequences}

To further characterize these gregarines, a molecular study was designed to sequence most of the SSU rDNA locus from gamonts and gametocysts, isolated from several host specimens belonging to L. migratoria and two subspecies of $S$. gregaria (Table 2). A total of 23 sequences were generated from gregarines found in 7 specimens of L. migratoria on three collection dates, and 20 sequences were generated from gregarines found in five specimens of $S$. gregaria from a total of three geographical origins and/or raising facilities (Table 3). Regardless of the subspecies and the geographical location of hosts and their maintenance facilities, all the gregarines isolated from $S$. gregaria specimens shared the same "type 1" sequence (1638-bp long), presumably corresponding to G. garnhami, whereas all the gregarines isolated from L. migratoria specimens presented a clearly distinct "type 2" sequence (1637-bp long), presumably corresponding to G. acridiorum. Multiple sequence alignment and distance analyses were performed to qualify intra-species and inter-species variations, and clearly revealed two distinct clusters (Fig. 2A). Within the sequence group of gregarines from the host $S$. gregaria, the mean level of divergence was $0.2 \%$, whereas within the sequence group of gregarines from the host $L$. migratoria, the mean level of divergence was $0.3 \%$. The mean level of genetic distance between gregarine sequences from $S$. gregaria and those from L. migratoria was $1.5 \%$, whereas the genetic divergence from $G$. caledia, parasite of $C$. captiva, was $1.1 \%$ with the gregarine group from $L$. migratoria, but $2.2 \%$ with the gregarine group from $S$. gregaria. In all, 22 conserved polymorphic positions, rather evenly distributed along the SSU rDNA locus, were 


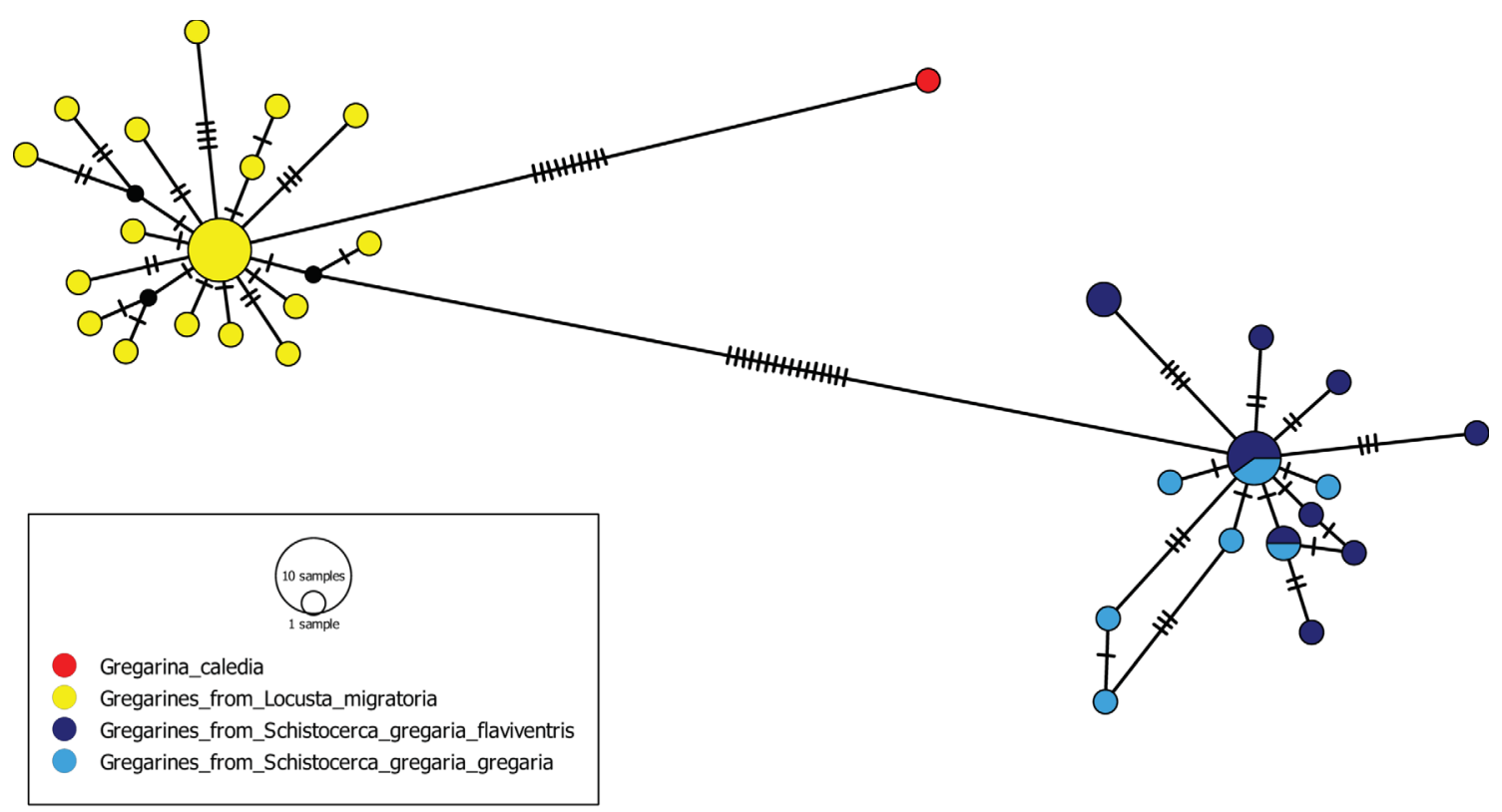

(A)

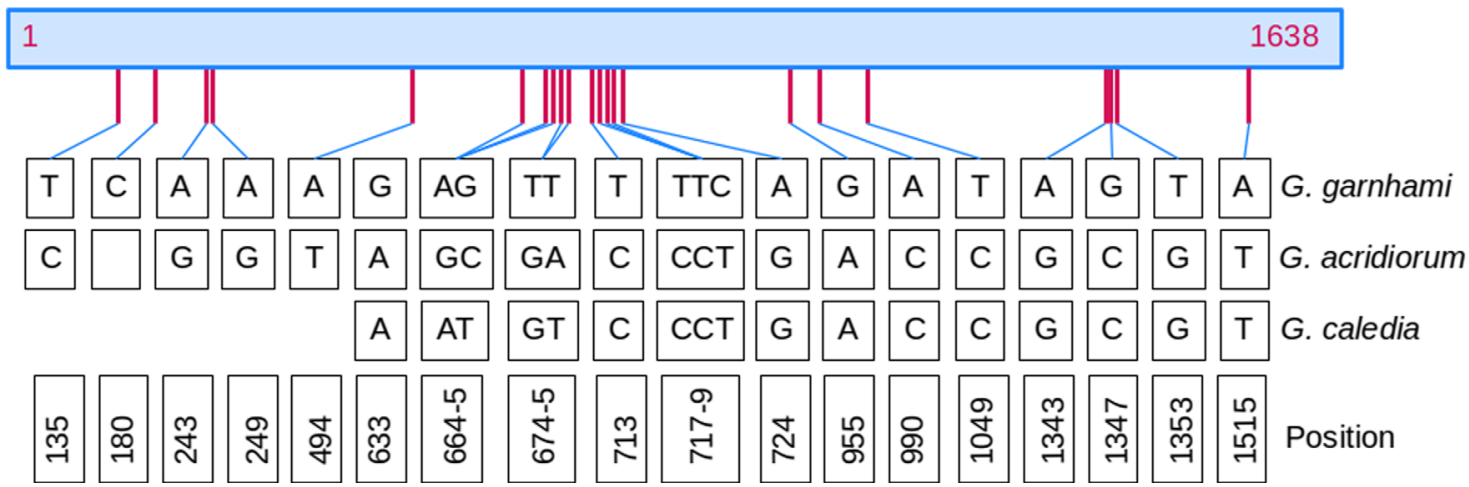

(B)

Figure 2. A: Minimum spanning network for the 43 cloned sequences of the SSU rDNA region studied, and the published sequence of $G$. caledia (L31799). Each link between haplotypes indicates one mutation, including indel events. The colors indicate the species or subspecies of the host. This network was inferred using POPART [25]. B: Distribution of the 22 polymorphic positions in SSU rDNA locus regions V1V8 (1638-bp), between type 1 (presumably G. garnhami) $(n=20)$ and type 2 (presumably G. acridiorum) $(n=23)$ sequences, amplified from gregarines parasitizing respectively $S$. gregaria and L. migratoria. The corresponding positions are also given for G. caledia (L31799, 1210 bp) parasitizing Caledia captiva. Eleven additional positions, otherwise conserved between G. garnhami and G. acridiorum sequences, are modified in G. caledia sequence: site 1059, G deletion; sites 1161-1164: GAGC substituted by AG-G; site 1181: G substituted for C; site 1187: G substituted for A; sites 1231 and 1240: T substituted for C; site 1493: T insertion; site 1584: G substituted for A.

identified between "type 1" and "type 2" sequences (assumed to be G. garnhami and G. acridiorum, respectively), as schematized in Figure 2B.

\section{Phylogenetic analysis}

A phylogenetic approach, using partial SSU rDNA sequences and both maximum likelihood and Bayesian inference reconstructions, indicated that gregarine sequences from the two different host species studied clustered with sequences from other Gregarinoidea species (as described in [9, 11, 35]) with a high ML bootstrap value and Bayesian posterior probability (Fig. 3). These novel gregarine sequences form two clearly distinct clades according to their host species, and it thus appears that all $S$. gregaria hosts, regardless of their subspecies and the geographical location at which they were maintained, were infected by the same species (based on their SSU rDNA sequence) that was clearly distinct from the parasitic species infecting L. migratoria. The SSU rDNA sequence from $G$. caledia showed closer affinity to gregarine sequences from the host L. migratoria than from the host S. gregaria (see also Fig. 2). Furthermore, we observed that hosts of the "type 2" (presumably G. acridiorum) and G. caledia sequences, i.e. L. migratoria and C. captiva, belong to the same clade B of the acridian phylogeny as defined by Song et al. 2018 [38], while S. gregaria, infested with G. garnhami ("type 1" sequences), belongs to a distinct clade $\mathrm{D}$, as indicated in Figure 3. Thus, gregarine distribution appears to parallel the 


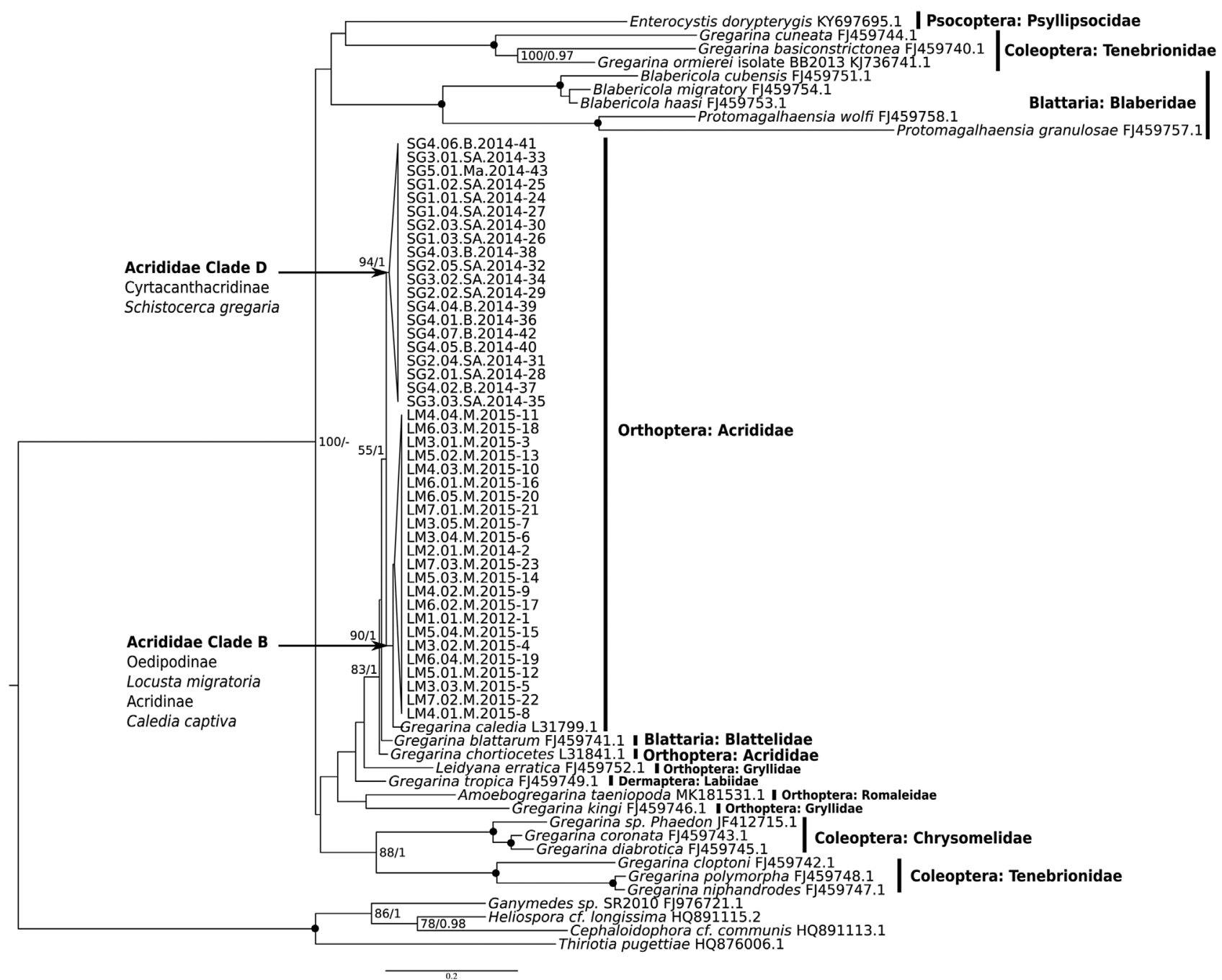

Figure 3. Phylogenetic tree built using 69 SSU rDNA sequences for 1,433 sites in order to zoom in on the clade Gregarinoidea including gregarines parasites of Orthoptera [11]. Outgroup consists of 4 sequences from Cephaloidophoroidea species that infect crustaceans, currently considered as the sister group of Gregarinoidea [29]. Evolutionary history is inferred by maximum likelihood and Bayesian inference using a GTR substitution model with gamma-distributed rate variation across sites plus invariant sites. Maximum likelihood topology is shown, with supports from both methods. Bootstrap $<75 \%$ and posterior probabilities $<0.95$ are not shown. Black spots indicate 100/1 supports. The gregarines infecting L. migratoria clustered with G. caledia, isolated from the grasshopper Caledia captiva [30], the gregarines infecting S. gregaria forming a distinct independent clade. G. chortiocetes, infecting the locust Chortiocetes terminifera [30], and Gregarina blattarum, infecting the cockroach Blatella germanica [11] form sister branches to this group. The taxonomy of locust hosts is indicated, as established by Song et al, [38].

taxonomy of these three hosts. This observation will however need to be confirmed, as the ML bootstrap support remains low (55), despite high Bayesian posterior probability (Fig. 3).

\section{Discussion}

To determine whether the acridian orthopterans $S$. gregaria and L. migratoria are infected by the same gregarine species, their parasites were isolated and morphological and molecular analyses were performed using a series of host specimens of both species collected from a range of different locations and insect raising facilities (Table 2). While morphological investigations confirmed highly similar parasites with only tenuous morphological and behavioral differences, molecular investigations yielded unambiguous results strongly supporting different gregarine species in these $S$. gregaria and L. migratoria hosts.

\section{Molecular data support distinct species}

Molecular characterization, based on the partial SSU rDNA marker (V1-V8 region [18]) of all gregarines studied, unambiguously demonstrated that all $S$. gregaria hosts - regardless of their subspecies and raising facilities - are infected by the same gregarine species (presumably G. garnhami), whereas all L. migratoria hosts are infected by a distinct species (presumably $G$. acridiorum). Both gregarine sequences clustered in the previously reported Gregarinoidea clade [11, 29, 31]. 
Overall, 22 different bases were identified in this $1638 \mathrm{bp}$ region that could be used to delimit the species. The $1.5 \%$ genetic distance between the two sequences is in agreement with previously described inter-specific levels of genetic divergence that, for example, distinguish Gregarina niphandrodes from Gregarina polymorpha (1.44\%) [31]. However, it should be noted that, according to the same authors, such "low" genetic divergence could also correspond to "intra-specific" variability [31]. Certainly, additional studies will be needed to clarify this issue, but we recently demonstrated that two marine gregarines with an almost identical SSU rDNA sequence (1 bp difference for 1702 positions, i.e. $\sim 0.05 \%$ divergence) displayed $\sim 10 \%$ overall nucleic acid divergence at the genomic level, preventing genetic crossing, i.e. arguing for different species (I. Florent and J. Boisard, unpublished data).

Based on these molecular results and on data in the literature, notably the identification of their hosts, we propose that the "type 1" sequence found in gregarines infecting $S$. gregaria hosts may correspond to the species named $G$. garnhami, reported by several authors and collected from $S$. gregaria [7, 42]. The gregarine species found in L. migratoria likely corresponds to G. acridiorum, in agreement with Léger [24], but not with the proposal of Lipa et al. [27].

\section{Some morphological and behavioral features discriminate the two species}

To further confirm that two distinct gregarine species infect S. gregaria vs. L. migratoria, we focused on their possibly discriminating morphological and behavioral differences. Several morphological characters have been proposed in the literature to discriminate acridian gregarines, including: (1) the number and length of sporoducts, (2) the size of oocysts, and (3) the presence of a sharply pointed posterior extremity in G. garnhami versus a rounded extremity in $G$. acridiorum gamonts (see Table 1), even though, as indicated by Lange and Wittenstein, 2002, "such morphological features are probably not sufficient to delimit species, as very similar values in ranges and ratios were found between them" [22].

The sporoducts were indeed shorter in gregarines that infect $S$. gregaria (Fig. 1E) than in gregarines that infect L. migratoria, (Fig. 1L), supporting the hypothesis that $S$. gregaria can be infected by G. garnhami ( 1/3 of the diameter of the gametocysts, Table 1$)$ and $L$. migratoria by $G$. acridiorum $(\sim 1 / 2$ of the diameter of the gametocysts, Table 1). The comparative study of sizes of barrel-shaped oocysts led to a less definitive indication. In gregarines that infect $S$. gregaria, the measurements $(6.54 \pm 0.32 \mu \mathrm{m} \times 4.32 \pm 0.23 \mu \mathrm{m}, n=89)$ closely matched those reported in the literature for $G$. garnhami (6.5-7 $\mu \mathrm{m} \times 4 \mu \mathrm{m}$, Table 1), compared to the remaining four species (Table 1). In gregarines that infect L. migratoria, these measurements $(6.83 \pm 0.27 \mu \mathrm{m} \times 3.99 \pm 0.19 \mu \mathrm{m}, n=40)$ somewhat resemble those proposed in the literature for $G$. acridiorum $(7.6 \times 3.3 \mu \mathrm{m}$, Table 1$)$, but are also very similar to the values reported for $G$. garnhami $(6.5-7 \mu \mathrm{m} \times 4 \mu \mathrm{m}$, Table 1). However, these measurements are clearly more distantly related to the measurements reported for oocysts of the three other morphologically similar species: G. rigida $(8 \mu \mathrm{m} \times 5 \mu \mathrm{m})$,
G. ronderosi $(5 \mu \mathrm{m} \times 3.2 \mu \mathrm{m})$, and $G$. caledia $(12 \mu \mathrm{m} \times 6 \mu \mathrm{m})($ Table 1$)$.

However, the sharp (G. garnhami) versus round (G. acridiorum) posterior extremity of gamonts, proposed as a distinguishing feature between these two species, was not always reliably observed in our study and was therefore not retained as a distinguishing feature. Also, the number of sporoducts per gametocyst, currently reported in the literature to be larger in G. acridiorum (12-15) than in G. garnhami (8) (see Table 1), does not support our hypothesis that $G$. acridiorum is present in L. migratoria and G. garnhami is present in $S$. gregaria, as we observed the contrary: the number of sporoducts was less than eight for gregarines infecting L. migratoria (Fig. 1L) and more than eight for gregarines infecting S. gregaria (Fig. 1E). However, as previously mentioned by Clopton et al., 2009, the number of sporoducts is probably an unreliable taxonomical character [11]. Gametocysts diameters were also larger in $G$. garnhami $(350 \pm 56 \mu \mathrm{m}, n=36)$ vs. G. acridiorum $(227 \pm 35 \mu \mathrm{m}, n=18)$, but with overlapping values (210-420 $\mu \mathrm{m}$ for $G$. garnhami; 190-296 $\mu \mathrm{m}$ for G. acridiorum).

In the course of this study, we identified a third distinctive feature that is rarely mentioned in the literature: the fact that gregarines were systematically observed in the ceca of $S$. gregaria but never in the ceca of $L$. migratoria. The presence of G. garnhami but also G. rigida, G. ronderosi and G. caledia in the ceca of their hosts has also been systematically reported (Table 1) but interestingly, only the midgut was reported to be infected in the host specimens examined by Léger 1893, which included L. migratoria [24]. Whether this behavioral difference results from differences between gregarine species, in terms of ecological niche or host-parasite relationship, or from anatomical specificities in the two infected hosts, as already suggested [4], needs to be investigated experimentally. This third difference further supports the hypothesis that the two gregarines that infect either $S$. gregaria or L. migratoria should be considered distinct species. Remarkably, the gregarines recorded by Lipa et al. [27] in different acridian species, developed in the midgut but also in the gastric intestinal ceca of their hosts, a habitat that could indicate that they were infected by G. garnhami rather than by $G$. acridiorum. Alternatively, these acridian species may have hosted entirely novel (cryptic) gregarine species that remain to be characterized.

In addition to the morphological and developmental differences described above, these two gregarines share many peculiarities such as the ectocyst and the orange basal discs involved in gametocyst encystment then dehiscence [17]. The ectocyst, which designates the thick outer gelatinous layer or translucent hyaline coat of the gametocyst, is found in a wide range of gregarines of Orthoptera and is probably an adaptation to the host environment that makes it possible to keep the developing gregarine in a moist atmosphere [17]. Basal discs, involved in the extrusion of the sporoducts of all gregarines belonging to the superfamily Gregarinoidea, are widely observed in Hexapoda hosts [17]. The basal discs are orange in all the gregarines of Orthoptera and the gamonts are often pale yellow, as we observed here for gregarines infecting both $S$. gregaria and L. migratoria hosts. Importantly, it is possible that these morphological features are the product of 
plasticity, so their taxonomical significance remains to be explored.

\section{Taxonomic consequences}

Based on these differences and on the available literature, we thus endorse the hypothesis that the species that infect $S$. gregaria should bear the species name G. garnhami, in agreement with the morphological characters established for this species (Table 1) and in agreement with a previous proposal by Valigurova and Koudela [42]. Indeed, these authors already disputed the interpretation of Lipa et al. (1996) [27] arguing that in their studies, Lipa et al. did not observe the developmental stages that are able to differentiate these species, i.e. the number and length of the sporoducts involved in the dehiscence process and the size and shape of their oocysts [42]. Concerning the species that infect $L$. migratoria, we maintain our proposal to name them G. acridiorum, even though only in partial agreement with the morphological characters established for this species (Table 1). This proposal is logical given the taxonomic history of this species, as the first Gregarina species found to infect L. migratoria was called Gregarina (Clepsidrina) acridiorum [21, 24], and the absence of colonization of the hosts's ceca. Although the size and shape of the oocysts we observed in the gregarine infecting L. migratoria do not perfectly match the measurements reported for G. acridiorum in the literature (Table 1), the size and shape of the oocysts we observed in gregarines that infect $S$. gregaria perfectly match the measurements reported for G. garnhami in the literature. However, the oocyst in gregarines found in L. migratoria were clearly thinner and longer than the oocysts in gregarines found in S. gregaria, observed in similar conditions. The observed length of sporoducts also agrees with data reported for both species in the literature, unlike the observed number of basal discs/sporoducts developing at the surface of gametocysts in dehiscence (Table 1). As mentioned above, this point should be interpreted with caution as it has been reported that the number of basal discs and the development of sporoducts may vary according to environmental conditions (temperature, hygrometry) as well as possibly the size of the gametocysts [7, 11].

\section{Morphological plasticity and host conditions}

The morphological data showed that the developmental stages of the gregarines infecting S. gregaria (Figs. 1A-1G) were generally very similar, though slightly longer and larger than the developmental stages of the gregarines infecting $L$. migratoria (Figs. $1 \mathrm{H}-1 \mathrm{M}$ ). However, depending on the raising facility and/or geographic origin, gregarines - notably trophozoites and gamonts - appeared to be slimmer in S. g. gregaria hosts from Morocco and S. g. flaviventris hosts from South Africa (not shown) than in gregarines infecting $S$. g. gregaria hosts from Belgium (Fig. 1D). The latter, which were much stockier, were more similar to the gamont stages of the gregarines that infect L. migratoria (Figs. 1H-1K). Since S. g. flaviventris hosts and S. g. gregaria hosts from the South African and Moroccan facilities, respectively, were also observed to be unhealthy (mature adults behaved sluggishly and seemed soft and light from food), while $S$. g. gregaria hosts from the Belgium facility and the L. migratoria hosts maintained in France did not seem to be particularly affected by the presence of their infecting gregarines (see also Table 2), we favor the hypothesis that environmental differences or co-occurring microorganisms may explain the difference in "fitness" between "African" and "European" hosts, as this was not due to infections by distinct gregarine species.

\section{How many distinct species are there for these gregarines?}

The gregarine developmental stages described in S. gregaria and L. migratoria hosts are very similar morphologically, and share many characteristics including the thick mucilaginous ectocyst of the gametocyst, orange basal discs associated with great variability of size parameters. As these morphological features have also been observed in other species, particularly in $G$. rigida, G. ronderosi and G. caledia collected from different (and sometimes from identical) orthopteran hosts (Table 1), these species need to be further characterized at the molecular level to solve their phylogenetic relationships. The only molecular sequence available (G. caledia, L31799) although rather small (1210 bp) strongly suggests a third distinct species, closely related phylogenetically to the proposed $G$. acridiorum but still with some observed genetic distance (1.1\%). Gregarina caledia is also potentially morphologically distinguishable by the larger size of its oocysts and its ability to infect host ceca (Table 1, [30]). Importantly though, in the first morphological reports, this species was said to be closely related to G. garnhami with which it also shares the ability to infect host ceca [30].

Gregarina rigida (Hall, 1907) Ellis, 1913, has also been reported in a range of orthopterans. When describing this species, the authors did not cite any literature on G. acridiorum, so, in 1968, Corbel concluded that G. rigida was a junior synonym of G. acridiorum [14]. To be confirmed, the status of this species (e.g. synonym of G. acridiorum?) therefore requires molecular data, even though available measurements of oocysts and the fact that it has also been found in host ceca (Table 1) favor a distinct species. Importantly, in 2002, G. ronderosi, which was found in the argentine grasshopper, Dichroplus elongatus, was named a novel species by Lange and Wittenstein due to the lack of infection in specimens of L. migratoria experimentally infected with this gregarine [22]. It thus also possibly corresponds to a fifth distinct species, also awaiting molecular characterization. Lange and Wittenstein, 2002, even suggested that $G$. ronderosi could be synonymous with G. garnhami, but that molecular data were required as morphometric differences did not enable conclusive delimitation of the species [22].

\section{Conclusion}

It is well documented that assigning protist species can no longer rely on morphological information alone, but should include molecular data in an integrated taxonomic approach $[5,6]$. The data presented here confirm that most morphological 
and morphometric differences cannot conclusively delimit closely related species, while molecular data can reveal clearly measurable differences. By strongly suggesting that $S$. gregaria is infected by G. garnhami, whereas L. migratoria is infected with $G$. acridiorum, our data suggest two important discriminating features: the respective size of the oocysts of G. garnhami and G. acridiorum, but also their location in their respective host's gut. The first consequence is that G. garnhami can no longer be considered a junior synonym of G. acridiorum, contrary to the proposal by Lipa et al. [27] and is therefore reinstated here as a valid taxon, in agreement with the proposal of Valigurova and Koudela [42].

The exact distribution of G. garnhami and G. acridiorum in Orthoptera remains to be further investigated at this stage as clearly, when synonymized, they were assumed to infect the same series of host species [17]. Additional studies, specifically molecular studies, are crucial to determine the diversity of gregarine species that infect acridians, beyond the establishment of morphological specificities (see Table 1). This could help determine whether $G$. rigida and $G$. ronderosi are in fact distinct species or should be synonymized with other species. Interestingly, G. caledia, a parasite of the Australian locust $C$. captiva reported to be very similar to $G$. garnhami and for which molecular data are available [30], should be considered a species distinct from both G. garnhami and G. acridiorum as argued in this paper. Based on our molecular studies, G. caledia presents closer phylogenetic similarity to $G$. acridiorum (Fig. 3). A major challenge concerns the precise diversity of the species $G$. acridiorum that has been described in over 60 orthopteran hosts, from both the Caelifera and Ensifera orders, as is also the case for G. rigida. It is likely that these two species correspond to a much greater diversity of probably cryptic species that remain to be described by this type of integrative taxonomical approach, in the diversity of their currently described hosts.

\section{Conflict of interests}

The authors declare that they have no conflict of interest.

Acknowledgements. This work was supported by a grant from the French Agence Nationale de la Recherche [LabEx ANR-10-LABX0003-BCDiv], in the program "Investissements d'avenir" [ANR-11IDEX-0004-02], by several interdisciplinary Programs of the MNHN (ATM-Microorganismes, ATM-Génomique et Collections, ATMEmergence, AVIV department), the CNRS (Julie Boisard's PhD fellowship, 2018-2021) and the French Agricultural Research Centre for International Development (CIRAD). We are very grateful to Laure Wasniewski and Judykaelle Fede for providing the first molecular data on the gregarines infecting L. migratoria, to Lisy Ravendran for technical assistance with SEM sample preparation, to Geraldine Toutirais and the MNHN Platform (Plateau technique de Microscopie Électronique, Muséum National d'Histoire Naturelle MNHN, Paris, France, http://ptme.mnhn.fr/) for SEM image acquisition, to Laure Benoit for assistance with network figure and locust sample preparation, and to Hélène Jourdan for stimulating discussions at an early stage of the study. We are grateful to J. Vanden Broeck and C. Piou, for providing desert locust egg pods from the University of Leuven and from the CNLA of Agadir, Morocco.

\section{References}

1. Adl SM, Bass D, Lane CE, Lukes J, Schoch CL, Smirnov A, Agatha S, Berney C, Brown MW, Burki F, Cardenas P, Cepicka I, Chistyakova L, Del Campo J, Dunthorn M, Edvardsen B, Eglit Y, Guillou L, Hampl V, Heiss AA, Hoppenrath M, James TY, Karnkowska A, Karpov S, Kim E, Kolisko M, Kudryavtsev A, Lahr DJG, Lara E, Le Gall L, Lynn DH, Mann DG, Massana R, Mitchell EAD, Morrow C, Park JS, Pawlowski JW, Powell MJ, Richter DJ, Rueckert S, Shadwick L, Shimano S, Spiegel FW, Torruella G, Youssef N, Zlatogursky V, Zhang Q (2019) Revisions to the classification, nomenclature, and diversity of Eukaryotes. Journal of Eukaryotic Microbiology, 66(1), 4-119.

2. Allain T, Chaouch S, Thomas M, Vallee I, Buret AG, Langella P, Grellier P, Polack B, Bermudez-Humaran LG, Florent I. 2017. Bile-salt-hydrolases from the probiotic strain Lactobacillus johnsonii La1 mediate anti-giardial activity in vitro and in vivo. Frontiers in Microbiology, 8, 2707.

3. Ayali A. 2019. The puzzle of locust density-dependent phase polyphenism. Current Opinion in Insect Science, 35, 41-47.

4. Bernays EA. 1981. A specialized region of the gastric ceca in the locust, Schistocerca gregaria. Physiological Entomology, 6(1), 1-6.

5. Berney C, Ciuprina A, Bender S, Brodie J, Edgcomb V, Kim E, Rajan J, Parfrey LW, Adl S, Audic S, Bass D, Caron DA, Cochrane G, Czech L, Dunthorn M, Geisen S, Glockner FO, Mahe F, Quast C, Kaye JZ, Simpson AGB, Stamatakis A, Del Campo J, Yilmaz P, de Vargas C. 2017. UniEuk: Time to speak a common language in Protistology! Journal of Eukaryotic Microbiology, 64(3), 407-411.

6. Boenigk J, Ereshefsky M, Hoef-Emden K, Mallet J, Bass D. 2012. Concepts in protistology: species definitions and boundaries. European Journal of Protistology, 48(2), 96-102.

7. Canning EU. 1956. A new Eugregarine of locusts, Gregarina garnhami n.sp., parasitic in Schistocerca gregaria Forsk. Journal of Protozoology, 3(2), 50-62.

8. Castresana J. 2000. Selection of conserved blocks from multiple alignments for their use in phylogenetic analysis. Molecular Biology and Evolution, 17(4), 540-552.

9. Cavalier-Smith T. 2014. Gregarine site-heterogeneous $18 \mathrm{~S}$ rDNA trees, revision of gregarine higher classification, and the evolutionary diversification of Sporozoa. European Journal of Protistology, 50(5), 472-495.

10. Chapuis MP, Bazelet CS, Blondin L, Foucart A, Vitalis R, Samways MJ. 2016. Subspecific taxonomy of the desert locust, Schistocerca gregaria (Orthoptera: Acrididae), based on molecular and morphological characters. Systematic Entomology, 41(3), 516-530.

11. Clopton RE. 2009. Phylogenetic relationships, evolution, and systematic revision of the septate gregarines (Apicomplexa: Eugregarinorida: Septatorina). Comparative Parasitology, 76, 167-190.

12. Corbel JC. 1967. Intensité, fréquence et facteurs des infections grégariniennes chez les Insectes Orthoptères. Annales de Parasitologie Humaine et Comparée, 42, 373-385.

13. Corbel JC. 1968. New or poorly known gregarines parasitic on orthopterus insects. Annales de Parasitologie Humaine et Comparée, 43(3), 291-320.

14. Corbel JC. 1968. Parasitic specificity of gregarines of Orthoptera. Annales de Parasitologie Humaine et Comparée, 43(1), 25-32.

15. de Vargas C, Audic S, Henry N, Decelle J, Mahe F, Logares R, Lara E, Berney C, Le Bescot N, Probert I, Carmichael M, Poulain J, Romac S, Colin S, Aury JM, Bittner L, Chaffron S, Dunthorn M, Engelen S, Flegontova O, Guidi L, Horak A, Jaillon O, Lima-Mendez G, Lukes J, Malviya S, Morard R, 
Mulot M, Scalco E, Siano R, Vincent F, Zingone A, Dimier C, Picheral M, Searson S, Kandels-Lewis S, Acinas SG, Bork P, Bowler C, Gorsky G, Grimsley N, Hingamp P, Iudicone D, Not F, Ogata H, Pesant S, Raes J, Sieracki ME, Speich S, Stemmann L, Sunagawa S, Weissenbach J, Wincker P, Karsenti E. 2015. Ocean plankton. Eukaryotic plankton diversity in the sunlit ocean. Science, 348(6227), 1261605.

16. Del Campo J, Heger TJ, Rodriguez-Martinez R, Worden AZ, Richards TA, Massana R, Keeling PJ. 2019. Assessing the diversity and distribution of apicomplexans in host and freeliving environments using high-throughput amplicon data and a phylogenetically informed reference framework. Frontiers in Microbiology, 10, 2373.

17. Desportes I, Schrével J. 2013. Treatise on Zoology - Anatomy, Taxonomy, Biology. The Gregarines, The early branching Apicomplexa (2 vols). Brill. p. 791.

18. Hadziavdic K, Lekang K, Lanzen A, Jonassen I, Thompson EM, Troedsson C. 2014. Characterization of the 18S rRNA gene for designing universal eukaryote specific primers. PLoS One, 9(2), e87624.

19. Hussain KJ, Krishnan SM, Johny S, Whitman DW. 2013. Phenotypic plasticity in a gregarine parasite (Apicomplexa: Eugregarinordia) infecting grasshoppers. Comparative Parasitology, 80(2), 233-239.

20. Kumar S, Stecher G, Li M, Knyaz C, Tamura K. 2018. MEGA X: Molecular Evolutionary Genetics Analysis across Computing Platforms. Molecular Biology and Evolution, 35(6), $1547-1549$.

21. Labbé A. 1899. Sporozoa, Das Tierreich: Eine Zusammenstellung und Kennzeichnung der rezenten Tierformen. R. Friedlander und Sohn: Berlin, Germany. p. 180.

22. Lange CE, Wittenstein E. 2002. The life cycle of Gregarina ronderosi $\mathrm{n}$. sp. (Apicomplexa: Gregarinidae) in the Argentine grasshopper Dichroplus elongatus (Orthoptera: Acrididae). Journal of Invertebrate Pathology, 79(1), 27-36.

23. Léger L. 1892. Recherches sur les grégarines. Tablettes Zoologiques, 3, 1-182.

24. Léger L. 1893. Sur une grégarine nouvelle des Acridiens d'Algérie. Comptes Rendus de l'Académie des Sciences de Paris, 117, 811-813.

25. Leigh JW, Bryant D. 2015. Popart: full-feature software for haplotype network construction. Methods in Ecology and Evolution, 6(9), 1110-1116.

26. Levine ND. 1988. Progress in taxonomy of the Apicomplexan protozoa. Journal of Protozoology, 35(4), 518-520.

27. Lipa JJH-CP, Santiago-Alvarez C. 1996. Gregarines (Eugregarinorida: Apicomplexa) in natural populations of Dociostaurus maroccanus, Calliptamus italicus and other Orthoptera. Acta Protozoologica, 35, 49-59.

28. Mahé F, de Vargas C, Bass D, Czech L, Stamatakis A, Lara E, Singer D, Mayor J, Bunge J, Sernaker S, Siemensmeyer T, Trautmann I, Romac S, Berney C, Kozlov A, Mitchell EAD, Seppey CVW, Egge E, Lentendu G, Wirth R, Trueba G, Dunthorn M. 2017. Parasites dominate hyperdiverse soil protist communities in Neotropical rainforests. Nature Ecology \& Evolution, 1(4), 91.
29. Medina-Duran JH, Mayen-Estrada R, Marino-Perez R, Song H. 2020. Morphology and Phylogenetic position of two new gregarine species (Apicomplexa: Eugregarinorida) parasitizing the Lubber Grasshopper Taeniopoda centurio (Drury, 1770) (Insecta: Orthoptera: Romaleidae) in Mexico. Journal of Eukaryotic Microbiology, 67(1), 4-17.

30. Ninham JA. 1995. Phylogenetic analysis of five protoctist parasites of insects. PhD thesis. Australian National University: Canberra.

31. Nocciolini C, Cucini C, Leo C, Francardi V, Dreassi E, Carapelli A. 2018. Assessing the efficiency of molecular markers for the species identification of Gregarines Isolated from the Mealworm and super worm midgut. Microorganisms, 6(4), 119

32. Portman N, Slapeta J. 2014. The flagellar contribution to the apical complex: a new tool for the eukaryotic Swiss Army knife? Trends in Parasitology, 30(2), 58-64.

33. Ronquist F, Teslenko M, van der Mark P, Ayres DL, Darling A, Hohna S, Larget B, Liu L, Suchard MA, Huelsenbeck JP. 2012. MrBayes 3.2: efficient Bayesian phylogenetic inference and model choice across a large model space. Systematic Biology, 61(3), 539-542.

34. Sambrook J, Russell DW. 2006. Purification of nucleic acids by extraction with phenol:chloroform. Cold Spring Harbor Protocols, 2006(1).

35. Schrével J, Valigurova A, Prensier G, Chambouvet A, Florent I, Guillou L. 2016. Ultrastructure of Selenidium pendula, the type species of Archigregarines, and phylogenetic relations to other marine Apicomplexa. Protist, 167(4), 339-368.

36. Seck AG, Toguebaye BS. 1995. Étude taxonomique de quelques grégarines (Protozoa, Apicomplexa) parasites de criquets du Sénégal. Description d'Actinocephalus pyrgomorphae n. sp. Bulletin de l'Institut Fondamental d'Afrique Noire Cheikh Anta Diop Sénégal, série A, 48, 37-47.

37. Semans FM. 1941. Protozoan parasites reported from the Orthoptera, with special reference to those of Ohio. III. Protozoan parasites in relation to the host and the host ecology. Ohio Journal of Science, 41, 457-464

38. Song H, Mariño-Pérez R, Woller DA, Cigliano MM. 2018. Evolution, diversification, and biogeography of grasshoppers (Orthoptera: Acrididae). Insect Systematics and Diversity, 2(4), 3, $1-25$.

39. Souidenne D, Florent I, Dellinger M, Justine JL, Romdhane MS, Furuya H, Grellier P. 2016. Diversity of apostome ciliates, Chromidina spp. (Oligohymenophorea, Opalinopsidae), parasites of cephalopods of the Mediterranean Sea. Parasite, 23, 33.

40. Stamatakis A. 2014. RAxML version 8: a tool for phylogenetic analysis and post-analysis of large phylogenies. Bioinformatics, 30(9), 1312-1313.

41. Uvarov BP. 1977. Grasshoppers and Locusts, vol. 2, Centre for Overseas Pest Research: London.

42. Valigurova A, Koudela B. 2008. Morphological analysis of the cellular interactions between the eugregarine Gregarina garnhami (Apicomplexa) and the epithelium of its host, the desert locust Schistocerca gregaria. European Journal of Protistology, 44(3), 197-207.

Cite this article as: Florent I, Chapuis MP, Labat A, Boisard J, Leménager N, Michel B \& Desportes-Livage I. 2021. Integrative taxonomy confirms that Gregarina garnhami and G. acridiorum (Apicomplexa, Gregarinidae), parasites of Schistocerca gregaria and Locusta migratoria (Insecta, Orthoptera), are distinct species. Parasite 28, 12. 
An international open-access, peer-reviewed, online journal publishing high quality papers on all aspects of human and animal parasitology

Reviews, articles and short notes may be submitted. Fields include, but are not limited to: general, medical and veterinary parasitology; morphology, including ultrastructure; parasite systematics, including entomology, acarology, helminthology and protistology, and molecular analyses; molecular biology and biochemistry; immunology of parasitic diseases; host-parasite relationships; ecology and life history of parasites; epidemiology; therapeutics; new diagnostic tools.

All papers in Parasite are published in English. Manuscripts should have a broad interest and must not have been published or submitted elsewhere. No limit is imposed on the length of manuscripts.

Parasite (open-access) continues Parasite (print and online editions, 1994-2012) and Annales de Parasitologie Humaine et Comparée (1923-1993) and is the official journal of the Société Française de Parasitologie. 